\title{
Defining A Canadian Approach To Municipal Consolidation In Major City-Regions
}

\section{Jim Lightbody}

University of Alberta

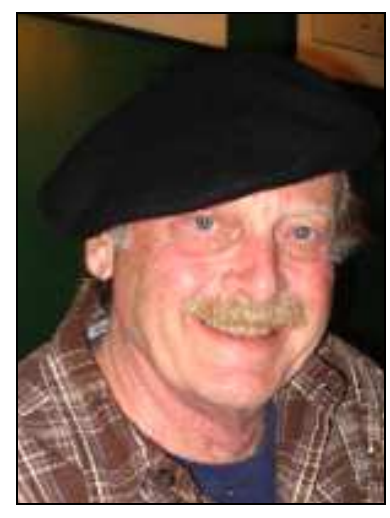

\section{Abstract}

Where there is a central government with an exclusive mandate over municipalities, along with a state executive structure using the Westminster model, then the consolidation of squabbling municipalities within metropolitan boundaries becomes a distinct possibility.

A general model of municipal restructuring for the Canadian metropolis is more widespread than the superficially unique circumstances of each case might suggest. The thinking here is informed by Clarence Stone's urban regime model, which helps to clarify what influences constituted the political tipping point for central government action. The paper focuses primarily on the Toronto and Montreal city-regional municipal consolidations at the end of the last century.

It is argued that the decisive element in setting the stage for significant change lay in the pervasive influence of corporate Canada in generally shaping provincial political discourse. What has not previously been of much interest for investigators is the matter 
of direct consequences for the low politics of city-regional governance. As will be seen, they were both tangible and considerable.

Key words: Canadian city-regions, central-local relations, metro government, Montreal, municipal consolidations, Toronto, urban regimes

\section{Introduction}

Across the twentieth century, institutionally entrenched municipal opposition to any suggestion of externally imposed structural consolidation, frequently justified by evocative appeals to sustaining historic patterns of democratic accountability, came to be widely accepted as sufficient to forestall mergers no matter what validity they might have in terms of fiscal efficiency, governing effectiveness, enhanced international entrepreneurial competitiveness, or simple regional survival as a viable entity.

Even so, over the last decade of that century the governments of Canada's two largest provinces, Ontario and Quebec, were both able to restructure not only their entire systems of local governance, but also that of their major city-regions. It is the latter of these moves that is of interest here. Why did city-region municipal consolidation proceed so dramatically in Canada, given its conspicuous failure in the United States when faced with opposition from a roughly similar fractious cacophony of forces?

One obvious explanation lies in the delineation of powers and the structuring of authority in formal constitutions. Where there exists a central government with an exclusive mandate over municipalities, and a state executive structure along the lines of the Westminster model, then the fusing of the squabbling municipalities within metropolitan boundaries becomes a distinct possibility. It must be observed that some type of central power to consolidate local institutions is pretty much the standard situation in all postindustrial democratic states except America. Hence the real potential for significant structural intervention has always existed in the Canadian provinces as it also does, for example, in the Australian states. This power was exercised in Canada, during a short decade of centripetal adaptation beginning in 1995 at the end of which half of the ten largest Census Metropolitan Areas (CMAs) - London, Winnipeg, Calgary, Hamilton and Ottawa - were completely unitary in municipal structure. The Toronto city-region's core was consolidated in 1998 and all of Quebec's CMAs were variously consolidated by 2002. Of the ten, only the local governments in Edmonton and the Greater Vancouver 
Regional District (GVRD) avoided mergers and can instead contemplate a future based on regional "cooperation" among municipalities along the lines of American-style Council of Governments.

This paper focuses on the origins and process of the Toronto and Montreal city-regional municipal consolidations in the last years of the last century. It is informed by elements adapted from the urban regime model advanced by Clarence Stone (1989) to help clarify what influences constituted the political tipping point for central government action. While the pivotal role of ministerial personalities in the small worlds of sub-national politics in giving the final go-ahead cannot be discounted (including especially the Premier of Ontario), it will be argued that a more conventional policy source in the respective communities provided the decisive element in setting the stage for significant change. While the pervasive influence of corporate Canada in shaping the public ideology sustaining provincial political discourse and policy systems has been well documented through long-standing social science research, what has not been of much interest is the matter of direct consequences for the low politics of city-regional governance. As will be seen, they were both tangible and considerable.

A general model of municipal restructuring for the Canadian metropolis is more widespread than the superficially unique circumstances of each case might suggest. Restructuring is more pragmatic than ideological at its core, and comes into play only after incremental patchworks of bilateral contracting, single purpose districting, or twotier municipal federation have been judged to fail as solutions to the problems of metropolitan governance. The earliest federative steps (Toronto 1954, Winnipeg 1961 and Montreal 1969) established metropolitan mechanisms to build the infrastructure for the spatial expansion of city-regions. Business leaders were generally so impressed with the concrete results that they paid virtually no attention to the policy-making process at the metro level (Kaplan 1967, p. 173). These early policy choices set a pattern by which a new information-based economy could later realize its own infrastructure requirements. A city-regional 'government' would enable industry clustering, an urban ecology attractive to a highly skilled and more cosmopolitan labour pool, and electronic infrastructure that worked. To world-aware entrepreneurs, continued incremental adjustment of government structures was quickly seen to be as incompatible with new political immediacies as were rust-belt warehousing capacities with IT development. 
In the theoretical world, legitimacy in the policy debate between centripetal and centrifugal local governing options for city-regions has generally been appropriated by American scholarship and largely by students in the public choice tradition of Charles M. Tiebout (1956). The underlying strength of this approach, which assumes that all citizens are both rational and perfectly mobile in matching location choices with municipal service levels and taxation rates, is that the state need not produce in order to provide services. Thus, multiple local governments within a city-region promote efficiency and effectiveness through competition both among them and with private sector providers, offer diversity of residential choice, and enhance citizenship opportunities in involvement and co-production (Stephens and Wikstrom 2000, pp. 107-21; Dowding 1994). This anti-hierarchical approach inherently tries to reduce, if not eliminate, the assumed inefficiency of monopoly public providers.

Aspects of public choice have been deployed as a theoretical foundation for the governmentally polycentric CMA that is attractive to both elected and administrative local public officials (Sancton 1994). For instance, case studies in the 'reinventing government' tradition of Osborne and Gaebler (1992) have been used to validate status quo polycentric government in the public eye. Where the general theory comes up short is when the parochialism entrenched by autonomous suburbs limits the possibilities for re-distributive social or environmental policies across the city-region.

To look beyond the sudden dramatic bursts of policy theatre surrounding (Megacity) Toronto in 1998, or Montreal in 2000 (or Unicity Winnipeg in 1971), then what was done and why can be set into better theoretical context as the comparative use of the public record permits a general explanation to unfold. Moves for restructuring assume consistent dimensions, in hindsight quite familiar to coffee shop patrons as well as the expert observer. It is a process comprised of three sequential, but roughly overlapping, stages.

\section{Conditions conducive to change in the Canadian city-region}

If applied to Canadian city-regions the observations of private power by Clarence Stone would be astute: each metropolitan area is loosely guided by its own particular 'urban regime' even when there are different foci for policy expression (Stone and Sanders 1987, pp. 268-74). The central point in this is that 'urban regimes' are not statutory instruments: "Urban regimes are arrangements for acting, for accomplishing policy 
goals, for managing friction points between groups, for adapting to an exogenous process of social change. These arrangements are informal; they enable public bodies and private interests to function together in making and implementing government decisions" (Stone 1989, p. 231). Even when the city-region has multiple municipal governments, urban regimes can establish limited common objectives, coordinate their activities and work through their differences. For the most part much of this important work is settled out behind the scenes.

As in America, the commercial community in Canada anchors urban regimes. Consequently, business interests with wider-area economic agendas can become decisive actors for many policy communities, not only because economic investment is so widely believed necessary to sustain a thriving urban community, but also because its leaders normally enjoy easy access to private channels of political influence. More successful regimes are inclusive of other interests to realize cooperative objectives, but they are not simply the sum of metropolitan 'governance' policy communities. They are defined by the very breadth of their focus, not by specialized policy involvement. Precisely because regime leadership is not exclusively centred in any one public policy arena, nor publicly obvious, it possesses a capacity for informal general control over disruptively centrifugal metropolitan tendencies. Commercial enterprise and its interest groups have proven most important because, as Stone has noted, of the perceived need to encourage economic investment and "the sometimes overlooked factor that businesses control politically important resources and are rarely absent totally from the scene" (1989, p. 7). Business is thus positioned as that part of the community, which can intervene for broader purposes at moments of genuine (or manufactured) social, political or economic stress.

If Stone's general analysis of the relationship of local power with municipal governing accurately describes the Canadian city-region circumstance, then the regime's generic problem with the governmentally fractured metropolis is that policy attention becomes preoccupied with very specific functional achievements (and monument building) within municipal borders: city-region focus is lost in the noise. Regime cadres are the first to notice that the urban myth of multiple distinct, self-sufficient and self-contained local communities requiring discrete municipal governments is simply not sustained by evidence (Lightbody 1997). 
By 1996 the ten largest CMAs in Canada averaged 30 units of municipal government, a number halved if Montreal (99) and Quebec City (44) were excluded. This count included neither secondary tiers in half the cases nor proximate municipalities adjacent to CMA boundaries. For instance, the actual 1998 commuting Montreal metropolis contained at least 135 front-line local governments. Also excluded from the average of 30 are school divisions, specific multi-lateral functional districts and any negotiated, quasi-governmental, inter-municipal service delivery arrangements. As to this last, for example, the Edmonton CMA (with 33 municipalities) included around 500 such agreements by the most recent (2000) accounting. If America with 117 units per cityregion were the absolute standard in governmental multiplicity, the Canadian experience would not appear too complex: New York City is but one of 1,787 governments and even Pittsburgh centres 323 (Savitch and Vogel 1996). On the other hand, the 6.7 million residents of Greater London survived a decade with only 32 boroughs and the City until the establishment of New Labour's 'government for London' in 1998. And Sydney, Australia, services 4.2 million people through 43 local governments.

Following the First World War twentieth century Canadian city-regions were carved into autonomous municipalities, which normally found it difficult to coordinate public activities for wider-area purposes. But while it appeared an especially difficult political task for individual local authorities to give an 'overall focus' to city-region public policies, it proved much easier for them to guard against any proposal to centralize dispersed authority. The point public choice apologists too often overlook is that municipalities in a polycentric agglomeration become political systems with their own legitimate and fully-fledged bureaucracies, clienteles and unique political organizations, all with standing vested in the status quo. While some localities persisted only for the limited advantages permitted clientele groups like suburban chambers of commerce, natural centrifugal inclinations had powerful roots in just how comfortable councillors and citizens as clients had become in working within established frameworks. For example, multiple formal governments served to keep land costs, front-end servicing charges and commercial tax rates 'competitive' in city-regions to the advantage of oldstyle development companies. But when historic local boundaries became grossly inconvenient, or as they impeded the emergence of a sustained and discernible metrolevel specialized public or policy community for regional governance, pressure could build quickly for change. 
Three predictable policy issues bedevil the city-region with multiple autonomous jurisdictions: (a) to coordinate public policies between and among multiple local governments; (b) to devise more open lines of accountability for the choices made (or not taken); (c) to provide some measure of equity for citizens as taxpayers both in service delivery and in generating revenues (Lightbody 2006, pp. 409-10). The common heart of the matter is the design of problem-solving governing units, which have some congruence with recognized problems. Failure to respond adequately to one or more of these generic problems may be sufficient in and of itself to precipitate a restructuring initiative in any specific case.

Redistributive matters have seldom been directly addressed in the municipal public policy sphere in Canada. Aside from the Winnipeg initiative, even where inequity was blatant as in the Quebec City and Montreal city-regions this matter seldom became much of an issue during municipal restructuring. Harold Kaplan did observe that in the Winnipeg two-tier Metro Government period (1961-71), two-thirds of the regional level's revenues derived from within the City of Winnipeg while most of its programs were principally of benefit to the urbanizing suburbs (1982, p. 552). By 1971, average family incomes among the cities of Winnipeg showed the richest community enjoyed incomes four times those of the poorest, and 350 per cent of the CMA average. For even the second highest income community the numbers were 144 per cent and 125 per cent. By comparison, in Montreal, the divergence was 316 and 445 per cent, and Marie-Odile Trepanier has noted how stubbornly the wealthier inner suburbs clung to their independence (1993, p. 70).

In the polycentric American metropolis the economic structure of inequality and the social disparity with which it correlated was once eviscerated by Norton Long in these terms: "The suburb is the Northern way to insure separate and unequal. It has the advantage of being legal" (1968, p. 247). But, unlike Canada, that autonomy comes with a virtually unfettered 'home rule' constitutional warranty. North of the border the preservation of upper income safe havens lies in the political instinct and not the judicial world.

Except for the nuisance factor for entrepreneurs of coping with the regulatory regimens of seven jurisdictions, Toronto and Montreal had pretty much become one city well before the provinces consolidated their municipalities. Lacking legs in equity issues, it 
was the coordination and accountability problems that dominated public political discourse about institutional incongruence with wider objectives. Redistribution was not even raised as an outstanding policy issue in the last studies of two-tier arrangements (Trepanier 1993; Frisken 1993, pp. 153-204). Perhaps metro Toronto's social housing strategy of dispersal across its region, with the necessary and concomitant community services, did contribute to perceptions of sameness around the boroughs. Shortly before their termination it was argued that two-tier governing models had become inefficient, ineffective and redundant (Lightbody 1997).

From his perspective in public choice, Andrew Sancton once made the point that no political structure could guarantee the result of effective regional planning: "Conceivably, if there is general agreement that regional planning is necessary, it will emerge without a regional government structure" (1994, p. 45). But this is the crucial point: superfluous complexity in city-region structures distracts from the capacity of the regime to focus on overall planning and diminishes the competence of the region itself to carry out longer-term public, public-private and indeed private governing choices. In Canada the absence of area-wide institutions meant there was no formal mechanism to legitimize whatever 'general agreement' may have been reached by whomever. While professional and business leaders in the urban regime are not normally interested in playing the regional governance game through existing municipal structures, there is nothing to prevent a more private quest for rule changes from those who do have the power to intervene to realize a generalized strategy. What, then, are the circumstances, which constitute the need to bend the political ear?

Study of Canadian urban regions has produced very little theoretical discussion of conventional interest group activity. Harold Kaplan once argued that the absence of formal interest articulation at the regional level resulted from a kind of dissociation between what a metro council had the formal power to accomplish, and any broader sort of social issue that was salient to the civic community (1967, pp. 158-59). There may be better explanations for continued low levels of observable city-regional group activity across Canada. (A) Group leaders see their clienteles as generally well represented among the low status politicians on municipal councils and are content to let the councillors protect the community and broker political undertakings, since resources are too finite to squander in low level opportunities. (B) Groups with area-wide horizons have worked in private, possibly even as individuals over cocktails, to satisfy broader 
specific ends and then to allow local officials to write the public policy. While benign motives may characterise regional Chambers of Commerce or recreational organizations, specific development interests have never hesitated to exploit close personal ties with municipal engineers and town planners to ensure future locations for regional trunk sewers and water mains. (C) Defining wider-area issues continues to be elusive for formal groups active in policy formulation in higher-level governments in the absence of quite specific and cathartic crises in the basic caretaking services that local governments do provide.

What local municipalities do with respect to planning and development is not usually of great concern to dominant players within Canada's urban regions. So as long as routine services are provided and planning is conducted at a reasonable level of professionalism the inefficiencies of multiple municipalities can be tolerated. Even non-profit service agencies that are partly publicly financed, such as shelters for abused persons, solicit funds and receive their clientele without much regard for local boundaries. Similarly, a well-established urban regime can normally accomplish broader objectives by many means other than through traditional governmental forms. But contexts do change and new spark-point initiatives to facilitate entry into the global economy, such as the installation of area-wide fibre optic capacity, were quickly understood to reach beyond the authority of existing institutions.

For a time, some style of two-tier government was adequate adaptation for less consequential regime adherents in Canada in opening up the 'small opportunities' phenomenon which Stone observed in Atlanta: "most people most of the time are guided, not by a grand vision of how the world might be reformed, but by the pursuit of particular opportunities" (1989, p. 235). The point is that opponents of systemic reorganization can forestall change by a tactic of partial steps. In Canada overt pressure for comprehensive city-region governmental integration was minimal. Plausible explanations for the different instances exist. For Montreal cultural (and linguistic) diversity sustained municipal differentiation and fully-fledged polities, sufficient to prevent provincial authorities - strongly interventionist in other policy worlds - from meddling until 2000. By 1988, the province of Quebec had even dismantled its own Montreal-centred administrative region. On the British Columbia lower mainland the urban regime informally took upon itself international economic promotion and subsequent policy initiatives have simply not required formal support through any city- 
regional tier. In another instance, the forty years of aimless regional evolution in the Edmonton CMA was kept adrift by the absence of any critical mass of established corporate head offices.

But economic and social conditions change and urban regimes are adaptive, while municipal boundaries are by definition static. So our concern is with the ways in which pressures for change play against the forces of inertia and, if in this scenario innovative change is best worked outside the spotlight, then the important question is about what prompted a provincial ministry's hand.

\section{Reaching the decision to restructure}

Leaders in an urban regime tend to focus on particular issues and, while the absence of an over-arching metropolitan authority may make things more difficult, so long as the focus remains specific, are content to leave existing institutions well enough alone. This abstention is most noticed when the interests of the region as a whole are not represented at any bargaining table. Who, for instance, could have been singularly responsible for vitalizing the waterfront of Toronto, the inlets of Vancouver, the archipelago of Montreal? To this question one might argue with Clarence Stone that: "Regimes involve arrangements ... providing a variety of small opportunities [which] often overshadows broader questions and makes it possible for governing coalitions to gain cooperation even though their larger goals enjoy only weak or even unpopular support" (1989, p. 235). In this light, municipal governments might have facilitated growth management at the local level even when they could not directly initiate much in the way of economic or social expansion.

To most Canadian and American observers at the time, city-region coincident governing instruments (and especially Toronto Metro in 1954) wrote 'paid' to long-standing issues of accountability for the physical direction of urban design (transit, freeways, waterworks). In their classic text, Bollens and Schmandt observe: "The metropolitan government concept is firmly established in the Toronto area", and they described it as "a permanent solution" (1982, p. 339). In the same year it was abolished Toronto Metropolitan institutions were labelled 'a jewel' by Katherine Graham and Susan Phillips (1998, p. 75). The 'miracle' of Toronto's original metro government was much noted from the US side, as in Victor Jones' foreword to Albert Rose's 1972 study in which he lauded it as "the only 'truly metropolitan government." Had anyone studied them from a 
similar wishful perspective each of the other two-tier structural sets in Canada would have evoked similar accolades. One cloaked limitation was well forecast by Norton Long: "the miracle of Toronto became even less miraculous as its metropolitan government turned to social politics and the problems of fiscal redistribution" (1968, p. 247). Very specific functional support for the growth machine worked; adaptive social policies in the now widened public sphere were more suspect.

To achieve regional social policies a kind of CMA coincident sub-government often emerged in the form of joint actions in service delivery by central government ministries. From this a growing awareness of the city-region as a singular community could have developed, except that each line department with functional responsibilities to local areas such as community services, health, environment (especially water and sewerage) tended to devise its own programs and regulations in splendid isolation from the others. Nor did any central agency emerge to play a strong coordinating role such as that once accomplished for London by Whitehall's Ministry for the Environment. The general consequence in Canada was only a limited city-region focus for any potential policy community. Consequently, any general model of municipal restructuring in Canada needs to take into account the accumulation of small grievances that builds pressure for major instrumental change.

Winnipeg's metropolitan federation (1961-71) imploded because it was a 'system' only through its conflicts, conflicts premised on a general belief held firmly by both tiers that the other had no right to exist (Kaplan 1982, pp. 597-98). Conflict concerning core city redevelopment escalated to a level at which any development became impossible. By 1969 a nearly unanimous public call for amalgamation by the metro council reflected the private appreciations of its senior bureaucrats. More importantly, it also represented the discreetly conveyed, through private links, less embroidered concerns of leaders within the Urban Development Institute, Winnipeg Real Estate Board, Downtown Business Association and the business editors of the daily newspapers.

Since the particular construction of the structural envelope varied somewhat from one city-region to the next this led to the frequent conclusion that each Canadian cityregional experience was unique. They were not. The important step lies at the point where leaders in the urban regime become persuaded that an integration of political authority is necessary to realize opportunities. In 1971, for example, the Manitoba 
Association of Architects supported the Unicity initiative citing concerns with "division in authority ... [and] duplication in jurisdiction" (Manitoba, 1971, p. 842). Because support of this sort is widely replicated across the regime and shared through multiple channels with central authorities, significant unification of metropolitan institutions proceeded independent of the underlying ideology of the party in power: Winnipeg in 1971 (New Democratic Party, NDP), Halifax in 1996 (Liberal), Toronto in 1998 (Progressive Conservative), Montreal in 2000 (Parti Quebecois). And while provincial intervention appeared bold at the moment, this was only because it was decisive. The need for structural change had already been privately tested for general fit with significant regime leadership. An example of one such 'fit' would be Toronto in 1997, where a survey by the Board of Trade of its 502 members found that 65 per cent favoured the municipal merger as announced, and only 17 per cent would opt for the status quo (Toronto Star: 4 March).

Led by business, Canadian urban regimes have focused their public pronouncements upon growing municipal support for regional economic expansion. In its editorial endorsing the 1997 Megacity consolidation, the generally liberal Toronto Star observed: "One of the factors that limits our economic development potential is that too many cities are chasing the same business prospects. Potential investors say they are confused by all this uncoordinated lobbying" (22 February, 1997). When three-quarters of the Board of Trade membership supported the elimination of one level of local government its chairman proclaimed that: "The borders of the municipalities have no meaning for businesses" (Toronto Star: 5 March, 1997). Twenty years earlier, in the 1971 Winnipeg case, business and professional leaders within the urban regime had been privately dismayed by the tax incentives and forgiveness measures, low priced serviced lands, and relaxed zoning regulations dealt out by the various suburbs (especially St. Boniface) in a cut-throat competition for commercial and industrial development. These concerns were conveyed through intermediaries to several ministers who had themselves served as Winnipeg, suburban or/and Metro councillors. The result was that the new social democratic NDP government could realize its modest redistributive policy goals on the back of small efficiencies afforded business leaders.

In light of the above it may be noted that arguments for the continued autonomy of suburban municipalities based on their being distinctive local communities were undermined, ironically, by their own booster passions, which homogenized the larger 
metropolitan regions as suburban officials sought to emulate the programs and instrumentalities of the core city. Frances Frisken detailed that, with respect to Toronto by the 1980s, "the six municipalities have become more like each other as the suburbs have become more fully developed and their populations more heterogeneous" (1993, p. 166). Acting independently these representatives had constructed a social city-region that roughly mirrored its economic basis.

Scarcely a year after the passing of the Toronto Act that established the single unified city in 1998, the provincial press gallery in Ontario was provided a preliminary spin for proposed reforms to the province's second largest CMA, Ottawa-Carleton. Describing "A capital mess”, Jeffrey Simpson wrote: “The vast majority of the Ottawa region's business community wants one city ... Having small communities competing with each other, and with the regional government, makes no sense to them, and they are right" (Globe and Mail: 20 August, 1999). Helping the media to frame the target in these terms seemed least likely to cost the governing party an electoral win: "Premier Mike Harris is convinced that the best way to counter leftish downtowners is to yoke them to councils dominated by suburbs" (Ibbitson, 1999). Wire service stories reported the assessment of intent by a prominent university lecturer that the provincial government of Ontario had acted on Megacity as it had because it "thought the city of Toronto was not behaving in a way that would make it clear it was open for business in the way the province of Ontario was open for business" (Toronto Star: 2 February, 1998). Not only open, but also with an implementing capability unfettered by "historic" but dysfunctional municipal boundaries.

It should surprise few that there will always be substantial opposition to local government restructuring from politicians and public officials whose careers are connected to particular municipalities. For instance, the 1971 Winnipeg change reduced the number of locally elected officials from 112 to 51, Toronto in 1997 meant 57 instead of 106, and the Montreal 2002 council of 73 replaces 290 individuals. However selfinterested these people may appear they still have the power to forestall integration in the absence of any substantial outside force. Simply put, in the usual case dispersed but entrenched political authority can defeat integrative efforts. Frank Smallwood noted thirty years ago that the relative intensity of those opposed to institutional change contrasted markedly with the apparently meandering interest of those in favour. The logic was simple: "The supporters of re-organization are generally fighting for marginal gains (eg. incremental increases in powers and finances), while the opponents of re- 
organization are usually fighting absolute losses (ie. their very existence as viable entities" (1972, p. 336). His list of protagonists in regional reform led to a conclusion that almost any such initiative was predestined to failure. But by focusing only on overt expressions of interest, Smallwood counted the needles while failing to notice the looming haystack.

Especially apparent in the ranks fearing absolute loss will stand particularized interests who have wrested policy commitments and a cosy working relationship from central city councils, managing in the process to become an institutionalized lobby. For a quite usual instance, gay and lesbian leaders from the City of Toronto argued that: "Certain communities hold certain values and other communities don't hold the same values, which is fine [but] if we're required to sit at the same table, we will lose those local values" (Globe and Mail: 21 February, 1997). Of further concern, particularly among central city appointed officials, is that professional standards established by councils past would be corroded by an influx of new (and presumably redneck) suburban councillors. In the 1997 Toronto case, one Public Health Board member argued that their "mandate to prevent illness and foster good health could be jeopardized in a larger, amalgamated city ... a lack of local government can lead 'to malaise, illness and disease" (Toronto Star: 4 March, 1997). The next day the director of the central Toronto food bank argued that amalgamation would definitely worsen the "losing battle with hunger" (Globe and Mail, 5 March, 1997). During restructuring periods in Canadian CMAs union interventions were, however, consistently limited to matters concerning job security and pay scales.

Proponents of integration are leaders in the urban regime who have established private access to the senior government, in Canada the provinces. Consequently they may generate public policy solutions quite independently of any that arise in the official world of the municipal government industry. While small cartels of municipal officials always appear to hold the upper hand in public, whenever regime interests see local boundaries as an impediment to longer range policy ambitions they have possessed the capacity, separate and pooled, to commit resources and influence change in private ways.

To be effective in accomplishing institutional adaptation these community influentials do not require media attention. Who was most in the public eye did not derail, delay or rework the Montreal 2001, Toronto 1998 nor the earlier Winnipeg 1971 initiatives. The legitimizing forces played their important but less conspicuous role behind the curtains in 
what was once called the half-light of politics. In other words, such quiet and pragmatic endorsement for wider area governing as the ministry finds necessary has been supplied outside press gallery scrutiny. The Winnipeg Chamber of Commerce encouraged, and then with a few small reservations openly endorsed the NDP legislation in 1971 (Manitoba 1971, p. 830). In the early weeks of the Toronto amalgamation that city's authoritative business paper editorialized that: "A consensus appears to exist that Metropolitan Toronto should no longer have two levels of government ..." (Globe and Mail: 27 February, 1997). Earlier a former member of both Toronto City and Metro councils, and established TV commentator, took the pulse 'of resident associations across metro' to find that: "The general drift is that most of the [well-connected and] better-off communities are split slightly in favour of amalgamation in the belief that, despite a lot of evidence to the contrary, a Megacity will cost less to run and that property taxes will be lower" (Vaughan, 1997). Montreal's labour unions endorsed island unification, reinforcing the more subtly expressed concerns of commerce that the municipal region was 'falling behind Toronto.' It is usually only well after the fact, and in the analysis and memoirs of participant-observers, that the pattern of the urban regime's behaviour is clearly recalled as having provided uncompromising support for governmental centripetalism (Brownstone, et al. 1983, pp. 30-31).

What is sometimes lost in the consideration of public policy determination in Canada is the base reality that the faction which sways the political judgment of the provincial premier on the most fundamental policy initiatives has, tautologically, commanded the most influence. Not always is the electoral equation paramount, although the Parti Quebecois did hold only 8 of the thirty seats on Montreal Island, the Ontario Conservatives were strongest in Toronto's suburban ring, and the Manitoba New Democrats had little but electoral dreams in most of Winnipeg's suburbs. By the persistent evidence in Canada since 1954, metropolitan area municipal consolidation has been forced when, through informal lines of access, private interests have been convincing that a more or less immediate first minister's decision is required to accommodate social change and to manage economic growth for a term longer than a single electoral mandate. The controversy of legitimizing follows in public after the choice has been made. 


\section{Debate and resolution}

Opponents of integration will make their case in public. These individuals have good access to local media by virtue of official positions, and the media have their own reasons for publicizing disputes. As media seek 'balanced' expressions for the wider-area presentation of 'the news' during re-organization periods, the multiple city hall pulpits create an illusion of more considerable opposition than actually exists. During the Winnipeg re-organization in 1971, for a typical instance, nine suburban mayors and councils, and all of their senior bureaucrats, flamed the Unicity legislation. Extensive opposition to integration thus seems to exist even though only a relative few with selfinterests are deeply concerned.

Garber and Imbroscio have observed a common enough phenomenon when they note, "that institutional forms create their own logic and weight through continued use" (1996, p. 598). In this sense the past comes to validate existing local government arrangements to the point that historic precedent renders the future impervious to any challenge but that from the most contrary mindset. Suburban councillors stand invariably in the status quo vanguard and they are quite prepared to deploy their public purses to sustain community dissent. Injudicious spending kept the case against Toronto going in 1997, for example, and with no ironic twist, 'Taxpayers Against Megacity' with but 12 members and no membership list received a grant of $\$ 20,000$ from the core city's outlay of $\$ 1,665,000$ to preserve itself (Toronto Star: 2 February, 1997). Nowhere do suburbs want to enlist in any consolidation of governments. Andrew Sancton has argued that language difference, being the principal variable of public significance on Montreal Island, was irrelevant at the metro council level where a powerful alliance of suburbs instead emerged to oppose Montreal's ambitions. He submits that suburbs anywhere would subscribe to its goals because "their leaders have no desire to lose power over local systems which have proven to be valuable sources of political influence, patronage or even personal profit" (1979, p. 248, my emphasis). In December 2000, five island suburbs organized referenda that produced a 94 per cent vote opposing amalgamation. Adhering to the practice of governments in the Westminster tradition the province ignored both the vote and a December $10^{\text {th }}$ protest march estimated at 40,000 persons. Electorates can be sanguine about council motivations however: 46 per cent of electors surveyed during the 1997 Toronto reform agreed with the proposition that area mayors "are merely trying to save their jobs" (Toronto Star: 2 March, 1997). 
After cabinet makes the decision, the political ministry listens only to whom it wants, consulting only to legitimate its main course. The line-up of stakeholders opposed is predictable and irrelevant since the choice was always taken in good knowledge of this. In Ontario the 1200 or so requests became 600 formal appearances (of 10 minutes duration) before the legislature all-party committee and, beyond public relations, had no impact on the government's legislation. Those opposed had already lost in the private corridors of policy access. In the Montreal committee hearings, the 27 suburban mayors were collectively allotted 60 minutes to express their views; there were no surprises. As the minister answerable for the 1971 Winnipeg amalgamation recalled to the author about positions opposing his ministry's, in sentences that may as well have been uttered by counterparts responsible for Toronto in 1997 or Montreal in 2000: "We knew they [suburban councils] were all opposed; we also knew all their arguments. So, there was no real point in talking".

Once nudged by urban regimes, provincial governments of right, left and centre have all introduced very similar amalgamations to Canadian city-regions, even when the public argument is couched in different terms. In all significant regards the language in Bill 103 amalgamating metro Toronto in 1997 under the very conservative Ontario government of Mike Harris is identical to that used by the Manitoba very social democratic government of Ed Schreyer which, by Bill 36, created Winnipeg Unicity in 1971. The central substance of Bill 170 for Montreal in 2000 was further emulation, not innovation. Party tag is simply irrelevant once in power, and for such 'administrative' housekeeping as municipal issues imply there is not much need to seek legitimacy by appeals to historic labels. Much like urban regimes themselves, ministries have concentrated on building a pattern of small opportunities, reciprocal payoffs, mutual loyalties, and so forth. In practice they become program managers. Since this behaviour is not unique to Canada it was not much of a surprise that a regional government for London (UK) became a priority for the new Labour government in 1997 nor, in the context of that city's international economic positioning, that even a Labour ministry would argue for its reforms in these terms: "The new strategic authority will work to improve London's competitiveness, creating a climate in which business can thrive and a city where people want to live and work" (Deputy Prime Minister, 1997, p. 2).

Finally, there should be no confusion among knowledgeable practitioners that the final choice is always to be made by provincial (or state, in Australia) cabinets. Subsequent 
recourse to the courts as occurred in the Toronto case with the challenge on 22 April 1997 using the Charter of Rights as pretext is but an analgesic to those facing instrumental bereavement. It is also a sure sign that the fundamental case has been lost politically. ${ }^{1}$ The Supreme Court of Victoria in Australia found similarly in the City of Melbourne appeal against forced amalgamation in February 1994: “... if the decision arrived at may be seen as upholding legislation which constitutes a usurpation of democratic rights ... the remedy is to be found in the political not the legal arena" (cited in Vince, 1997, p. 159).

Although the ends are pragmatic, the means are often dramatic. When they do act, Canadian provinces have produced restructuring changes in quick, bold, broad strokes. In rejecting the suburban challenge to the Megacity initiative, Mr. Justice J. Borins noted: "it was submitted that Bill 103 came as a surprise to most inhabitants of the municipalities as the restructuring of Metro Toronto, and the mode of its governance, were not included specifically in the government's 1995 election platform" (Borins, 1997, p. 9). In policy terms, the Winnipeg amalgamation had similarly come out of the blue (Lightbody 1978, p. 498). Immediately prior to his government's election NDP leader Ed Schreyer had indicated that he was prepared to jettison his party's well-known position endorsing amalgamation in favour of amendments to strengthen the metro government. Reorganizing Montreal (leave alone four other city-regions) was a component of no PQ policy platform. Being unexpected, these infrequent but powerful executive interventions overwhelm predictable resistance entrenched in existing public institutions. Once decided, the cabinet view prevails. Provincial politicians, not particularly concerned about the resolution of cities' internal policy problems one way or the other, initiated the reforms and then pushed them to conclusion.

What provinces ought to have learned is that opposition comes and goes quickly. Once the changes are made, the more quickly and certainly the better, people adapt to the new framework, find it generally an improvement and become sufficiently attached that they do not want any reversal.

The process period can have interesting moments, however. A common target provided by a major change to existing public policy frameworks may spark the emergence of a new social movement. This informal network among a broad range of otherwise divergent groups and, in other situations, widely dissimilar individuals, becomes unified 
in specific resistance. Such new citizen movements are both easily mobilized and quick to disappear. Some of these displays can be quite spectacular theatre indeed. In Montreal, a 10 December 2000 mass protest rally of an estimated 40,000 persons was convened and marched downtown. It was led by two suburban mayors following a 1950s Town of Mount Royal fire truck. In Toronto opponents to amalgamation paraded in a reenactment of Canada's 1837 rebellion and "the size of the march far exceeded the 800 or so pitchfork-bearing reformers who tumbled out of a tavern north of the city to begin their short-lived fight for responsible government 160 years ago". Police estimated 4000 demonstrators were led by a hay wagon drawn by percherons and carting Toronto's Mayor (Globe and Mail: 21 February, 1997).

The most noteworthy new social movement to have appeared was during the Toronto Megacity debate and labelled its effort 'Citizens for Local Democracy' (C4LD). In quick order, and galvanized by a small, dynamic and focused leadership cadre often at odds with the provincial government on other policy matters, the network mobilized loud weekly rallies of up to 1,500 citizens. Adherents mobilized through what became sophisticated networks stacked the legislature committee hearings, and it was not uncommon for all 44 speakers in a day to be opposed to the legislation. Residents' groups, 20 to 50 present at a time with numbers impossible to estimate metro-wide, met regularly to organize more traditional phone and canvass campaigns. But despite eloquent advocacy for a 'new localism' or for community-based forms of public participation presumed coincident with an assertive 'municipal citizenship,' active involvement quickly dissipated after the institutional assault on the historic municipal gothic was complete. Simply put, citizens are not so attached to their councils, as councillors would like us to believe.

\section{Observations}

On the evidence what is important to observe is that citizen acceptance of new municipal governments is quick to emerge. Former suburban mayors quickly became the new mayors of Halifax, Toronto and Montreal. Preliminary polling of Toronto residents also indicated such integration: by the spring of 1999, 70 per cent of Toronto residents agreed "that they were satisfied with life after amalgamation", and a second poll reported that 66 per cent of those providing an opinion "felt that amalgamation was a success" (Toronto, 1999). Even after reducing the number of Ontario municipalities through consolidation 
from 856 to slightly more than 550 , and eliminating some 1,200 locally elected officials in the process, the Harris government was re-elected with a majority.

The clearest investigation of the rapid social and political integration of citizens came five years after the extremely controversial imposition of Winnipeg Unicity. Indeed the Taraska investigating commission appeared almost astonished, considering the 'abhorrence' and 'widespread opposition' which had accompanied the amalgamation initiative, to report that: "Perhaps the single most noteworthy 'accomplishment' since the Act was passed is the general acceptance of unification". They note that the over 100 submissions made to them included numerous suggestions for improvements. "But none recommended the abandonment of the unified city, a return to the former two-tiered structure or, for that matter, a return to the pre-Metro situation of multiple autonomous municipalities" (Taraska, 1976, p. 10). In short, there existed a level of acceptance of the new institutions "that would have seemed scarcely credible five years ago" (Taraska, 1976, p. 10). By privately, and publicly, working the new instruments, the several components of Winnipeg's urban regime minimized lingering rancour while demonstrating its many small and newly realizable opportunities.

If there is a political lesson in a general understanding of re-organization in the Canadian city-region, it is that provinces should not be deterred from imposing integration when it is in the broader public interest. It is not necessary to await an unanticipated regional servicing crisis sufficient to force the hand as happened with all earlier two-tier metros. However it is configured the local urban regime ought to be remembered positively when it has pushed the province in the right direction. Opposition will always appear substantial but it will nonetheless be self-interested, narrowly based and transitory. This is hardly a pejorative statement; analysts should not be misled by the overt political conflict, which emerges through the media for it is essentially community theatre and largely irrelevant to what is happening. When leaders in an urban regime become convinced that change is necessary they will act behind the scenes to find the ear of the province. Once the provincial government becomes convinced that change is necessary it has the means to effect such change expeditiously - as it should. 


\title{
Endnote:
}

\begin{abstract}
${ }^{1}$ The reasons for the judgment rendered 24 July, 1997, included: 'I have already found ... that there is no constitutional requirement on the part of the government to consult electors prior to the introduction of legislation, or to be bound by the majority views of electors as to whether they approve, or disapprove, of proposed legislation.' (Mr. Justice J. Borins, In the Ontario Court of Justice.' Judgment re: Challenge to the City of Toronto Act 1997, S.O. 1997, c. 2,' 18) This last refers to a series of public relations plebiscite exercises conducted by Toronto's local councils through mail, e-mail, fax, newspaper coupon, hand delivery and ballot box (on 3 March, 1997) which produced a 76 per cent negative vote on turnout estimated at under 30 per cent (Toronto Star, 4 March, 1997). The dispassionate question put was 'Are you in favour of eliminating [your municipality name] and all other existing municipalities in Metropolitan Toronto and amalgamating them into a Megacity?' Thirty years earlier the Winnipeg suburb of St. James-Assiniboia had proposed a similar area-wide proposition, which idea the NDP provincial government rejected (as had PC Premier Roblin of one on the Metro question in 1961) with the wording to be 'Are you in favour of the Manitoba Government's 48-man council concept for Greater Winnipeg without knowing what it may cost? OR Would you prefer to keep your own local council and change the representation of the present Greater Winnipeg Metropolitan Council to be delegates from your local council?' (Winnipeg Free Press, 6 March 1971).
\end{abstract}

\section{References}

Bollens, J.C. Schmandt, H.J. 1982, The Metropolis: Its People, Politics, and Economic Life, $4^{\text {th }}$ edition, Harper and Row, New York.

Borins, Mr. Justice J. 1997, In the Ontario Court of Justice Judgment re: Challenge to the City of Toronto Act 1997 c. 2, S.O, Toronto.

Brownstone, Meyer, Plunkett, T.J. 1983, Metropolitan Winnipeg: Politics and Reform of Local Government, University of California Press, Berkeley.

Deputy Prime Minister, UK 1997, New Leadership for London: The Government's Proposals for a Greater London Authority, July 1997, HMSO, London.

Dowding, Keith 1994, 'Tiebout: A Survey of the Empirical Literature', Urban Studies, XXXI, 767-797.

Frisken, Frances 2007, The Public Metropolis: The Political Dynamics of Urban Expansion in the Toronto Region, 1924-2003, Canadian Scholars' Press, Inc, Toronto.

Frisken, Frances 1993, 'Planning and Servicing the Greater Toronto Area: The Interplay of Provincial and Municipal Interests', in Rothblatt, Donald M., Sancton, Andrew, eds. Metropolitan Governance: American/Canadian Intergovernmental Perspectives: Institute of Governmental Studies, University of California, Berkeley, pp. 153-204.

Garber, Judith A., Imbroscio, David L. 1996, 'The Myth of the North American City Reconsidered: Local Constitutional Regimes in Canada and the United States', Urban Affairs Review, 31, 5 (May), pp. 595-624.

Graham, Katherine, Phillips, Susan with Allan M. Maslove 1998, Urban Governance in Canada: Representation, Resources, and Restructuring, Harcourt, Brace, Toronto.

Ibbitson, John 1999, 'New city of Ottawa a capital idea', Globe and Mail, 25 September. 
Kaplan, Harold 1982, Reform, Planning, and City Politics: Montreal, Winnipeg, Toronto, University of Toronto Press, Toronto.

Kaplan, Harold 1967, Urban Political Systems: A Functional Analysis of Metro Toronto, Columbia University Press, New York.

Leo, Christopher, Brown, Wilson 2000, 'Slow Growth and Urban Development Policy', Journal of Urban Affairs, 22, 2 (Spring), pp. 190-213.

Lightbody, James 2006, City Politics, Canada, Broadview Press, Toronto.

Lightbody, James 1999, 'Canada's Seraglio Cities: Political Barriers to Regional Government', Canadian Journal of Sociology, 24, 2 (Summer), pp. 175-191.

Lightbody, James 1998, 'Council Multiplicity and the Cost of Governance in Canadian Metropolitan Areas,' Canadian Journal of Urban Research, 7, 1 (June), pp. 27-46.

Lightbody, James 1997, 'A New Perspective on Clothing the Emperor: Canadian Metropolitan Form, Function and Frontiers,' Canadian Public Administration, XXXX, 3 (Fall), pp. 436456.

Lightbody, James 1978, 'The Reform of a Metropolitan Government: The Case of Winnipeg, 1971,' Canadian Public Policy, IV, 4 (Autumn), pp. 489-504.

Long, Norton 1968, 'Political Science and the City,' in Leo F. Schnore, ed. Social Science and the City. New York: Praeger, pp. 243-262.

Manitoba 1971, Legislature Committee on Municipal Affairs, Transcript of Hearings (July).

Osborne, David, Gaebler, Ted 1992, Reinventing Government: How the Entrepreneurial Spirit is Transforming the Public Sector, Penguin, New York.

Sancton, Andrew 1994, Governing Canada's City-Regions: Adapting Form to Function, Institute for Research on Public Policy, Toronto.

Sancton, Andrew 1979, 'The Impact of language differences on metropolitan reform in Montreal,' Canadian Public Administration, XXII, 2 (Summer), pp. 227-250.

Savitch, H.V., Vogel, Ronald K. 1996, Regional Politics: America in a Post-City Age, Sage, Thousand Oaks.

Smallwood, Frank 1972, 'The Politics of Regional Government,' in Lionel Feldman and M.D. Goldrick, eds, Politics and Government of Urban Canada, Methuen, Toronto, pp. 333-343.

Stephens, G. Ross, Wikstrom, Nelson 2000, Metropolitan Government and Governance: Theoretical Perspectives, Empirical Analysis, and the Future, Oxford University Press, New York.

Stone, Clarence 1989, Regime Politics: Governing Atlanta, 1946-1988, University Press of Kansas, Lawrence.

Stone, Clarence, Sanders, Heywood, eds. 1987, The Politics of Urban Development, University Press of Kansas, Lawrence.

Taraska, Peter 1976, Report and Recommendations, Committee of Review, City of Winnipeg Act, Queen's Printer, Winnipeg. 
Tiebout, Charles M. 1956, 'A Pure Theory of Local Expenditures,' Journal of Political Economy, 64, 4 (October), pp. 416-24.

Toronto 1999, Building the New City of Toronto Status Report, June [http://www.city.toronto.on.ca/council/amal_report1.htm\#savings]

Trepanier, Marie-Odile 1993, 'Metropolitan Government in the Montreal Area,' in Rothblatt, Donald N., Sancton, Andrew, eds, Metropolitan Governance: American/Canadian Intergovernmental Perspectives, Institute of Governmental Studies, University of California, Berkeley, pp. 53-110.

Valpy, Michael 1997, 'Local democracy, tossing leaflets from an electronic sleigh,' Globe and Mail, 16 January.

Vaughan, Colin 1997, 'Ratepayers' groups gear up for Megacity,' Globe and Mail, 3 February.

Vince, Anne 1997, 'Amalgamations,' in Brian Dollery, Neil Marshall, eds, Australian Local Government: Reform and Renewal, Macmillan, Melbourne, pp. 151-71. 